\title{
Production and Purification of Biogas; A Research
}

\author{
Kunal P, Ashish R, M K Punith Prasad, Hemanth Kumar K J
}

\begin{abstract}
In recent trends, most of the countries in the world are switching over to renewable source of energy instead of conventional sources of energy. Bio gas is one of the most used source of renewable energy. Bio gas is clean and renewable energy source.Due to the changes in environment condition by burning of fossil fuels and others this has led to the development of Eco friendly practises. the one we are talking about is bio gas which is Eco friendly and can be produced easily just by using vegetable waste, rice, cow dung and the bio gas can be used for our day to day activities. In this review paper we are discussing about the various type's production and purification sources of Bio Gas.
\end{abstract}

\section{INTRODUCTION}

Biogas is a green source of energy which is produced by breakdown of organic matter by microbes such as methanogens in the absence of oxygen. Biogas is mainly a mixture of methane $\left(\mathrm{CH}_{4}\right)$ and carbon di oxide $\left(\mathrm{CO}_{2}\right)$ with small amounts of hydrogen sulphide $\left(\mathrm{H}_{2} \mathrm{~S}\right)$, moisture and siloxanes. The conventional energy sources would last only a bit more than half a century but the serious threat of using these sources is pollution which lead to greenhouse effect and acid rain. The main means in which pollution can be controlled and the non-renewable energy source can be preserved for future is the use of renewable energy sources. Biogas is one such promising renewable energy source which can be used instead of conventional energy sources. Unlike other renewable resources biogas plant doesn't require high initial investment which makes it suitable for houses to industries. In northern European countries such as Finland and Norway biogas is used to power the vehicles which is the recent innovation. Since biogas is basically conversion of waste into energy it solves the problem of waste management which creates a healthy environment around us and can also be used to generate revenue by producing it from waste.

Most of the countries in the world are switching over to renewable source of energy and one of the most used source of renewable energy is bio gas. and the one country that now we are talking about is Singapore where it has limited natural resources like tidal, wind energy and most part of the country is urbanized however there are few areas in the country where agriculture is done and that waste is being used for the bio gas

Revised Version Manuscript Received August 19, 2019.

Kunal P,Department of Mechanical Engineering, Vidyavardhaka College of Engineering, Mysuru, Karnataka, India. (email:kunalmutha1998.km@gmail.com)

Ashish R, Department of Mechanical Engineering, Vidyavardhaka College of Engineering, Mysuru, Karnataka, India. (email:ashishramesh24@gmail.com)

M K Punith Prasad, Department of Mechanical Engineering, Vidyavardhaka College of Engineering, Mysuru, Karnataka, India. (email:punithkumar199847@gmail.com)

Hemanth Kumar $\mathbf{K} \mathbf{J}$, Department of Mechanical Engineering, Vidyavardhaka College of Engineering, Mysuru, Karnataka, India. (email:hemanthkumar55551@gmail.com) production. By adopting this method wastage of products is recycled and agriculture waste is lowered and waste of

chicken used in bio gas is being used as manure and that of waste water is not wasted because it is re circulated in the system and the country is now pushing towards renewable sources so that the country is Eco friendly and the impact to the environment is less and renewable source of energy is cost effective and can also be used in agriculture and also it can earn revenues and it is not harmful to the society.

The research was about wobbe index a wobbe index is one which shows relation between burners and gas properties. In this study different substrate was used and the different substrate that was being used were hen manure, pig manure and pig blend with hen manure and the heat obtained by using this type was found to be high[1]-[3][4].

\section{DIFFERENT SOURCES OF BIO GAS PRODUCTION}

The main study of this was to produce bio gas using chicken waste and to generate bio gas to produce electricity this was done by putting chicken waste, waste water and aerobic digester and the output from this was about $1 \mathrm{MW}$ of power according to the factory clams and the use of integrated system being used in the bio gas plant helps in reusing the same materials for the production of the bio gas [5].

In this study it was found that from luminaria japonica when fermented using hydrolysis the production of bio gas was increased and the level of hydrogen and methane was found out to be $327.4 \%$ for hydrogen and $354.99 \%$ for methane and the production of hydrogen and methane was higher when compared by other methods [6].Moreover, the solid substrate is also one of the useful resource of bio gas [3].

Traditionally animal manure and sewage have been used as feedstock for biogas production. But any organic substance from leaves of sugar beets, waste from agriculture related industries, food and organic municipal wastes to agricultural wastes can be used. However, fats provide highest yield but retention time is very large relative to carbohydrates and proteins. Carbohydrates and proteins oxidize faster but yield is low compared to fats. Other pathogens or microbes inversely affect the yield, so it recommended that sterilization of feed stock be done before fermentation. Wastes from plants like maize and wheat corn gives the highest yield. Non -agricultural wastes like food

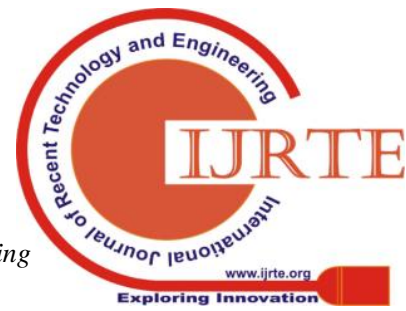


residue, used grease, etc. provide considerable increase in yield [7].

Sewage sludge is one of the most commonly used biomass along with feedstock (agricultural and non-agricultural) in wet fermentation. But in conventional digesters, degradation of sludge is slow, which leads to longer retention time. This can be solved by thermophilic anaerobic digestion, which significantly reduces the retention time and stabilizes the sludge. Thermophilic anaerobic digestion involves digestion of biomass at slightly elevated temperature of about $55 \mathrm{oC}$. It is observed that there is an increase of biogas production up to $50 \%$ due to heat treatment of sludge up to $70 \mathrm{oC}$ [8].

The previous researchers suggested the different sources of biogas. We can produce the Bio gas from the easy available sources. The production rate of the Bio gas is varying according to the sources. To improve the production of bio gas different method have been used such as; Additives, recycling of slurry and slurry filtration, variation in operational parameters like temperature etc.

\section{DIFFERENT TYPES OF PURIFICATION METHODS}

This article discusses the purification process of biogas by the use of biomass ash as a filter in order to entrap Carbon dioxide $\left(\mathrm{CO}_{2}\right)$ and Hydrogen sulphide $\left(\mathrm{H}_{2} \mathrm{~S}\right)$ to obtain pure methane. It was found that the mass of the biomass ash increased as crude biogas was passed through it, the reason for this was mainly due to the uptake of $\mathrm{CO}_{2}$ and $\mathrm{H}_{2} \mathrm{~S}$ by biomass ash. The uptake of $\mathrm{CO}_{2}$ was mainly due to carbonation reaction which converted all hydroxides present in ash to stable carbonates. The removal efficiency was found to be $33-36 \%$ during first 24-48hours. The removal efficiency of $\mathrm{H}_{2} \mathrm{~S}$ was just $50 \%$ for a duration of $14-18$ days. $\mathrm{H}_{2} \mathrm{~S}$ was removed as a result of iron purification due to the presence of $\mathrm{Fe}$ in biomass ash. It was determined that the removal of $\mathrm{CO}_{2}$ and $\mathrm{H}_{2} \mathrm{~S}$ per ton of ash was $35 \mathrm{~kg}$ and $0.56-1.25 \mathrm{~kg}$ respectively[9].

This paper discusses the influence of sheep manure and cow dung (without the use of inoculum) on biogas production and methanogenic communities. As the demand for biogas is increasing it is necessary to increase the biogas yield in a shorter period of time with the use of suitable substrates. Due to the presence of lignin in cow dung anaerobic digestion process becomes slow in order to fasten this digestion process sheep manure was used as a substrate and was tested. In the test it was found that cow dung had more methanobacteriales a type of archaea (methanogenic community) and it increased during the course of the reaction which was the reason for greater biogas yield but methanobacteriales number decreased during the course of reaction in sheep manure leading to lower biogas yield [10].

This paper discusses the technical and economic approach to capture $\mathrm{CO}_{2}$ by retrofitting a device to the biogas plant in order to capture $\mathrm{CO}_{2}$. Three retrofits were used and tested separately using gas engine- First system which captures $\mathrm{CO}_{2}$ from crude biogas by chemical absorption process Second system which captures $\mathrm{CO}_{2}$ after combustion of biogas by chemical absorption process and third system which captures $\mathrm{CO}_{2}$ after combustion of raw biogas with pure $\mathrm{O}_{2}$ instead of air (oxy-fuel combustion process). Moreover, after the comparison we have found that first system provides the better results compare with the other two systems[11].

However, Biogas is used for power generation as well as cooking purposes but the presence of large amounts of $\mathrm{CO}_{2}$ limits it to be used due the presence of excess $\mathrm{CO}_{2}$ which decreases the heating value of the fuel. Therefore, excess $\mathrm{CO}_{2}$ should be captured to enhance the heating value of the fuel. This article discusses the efficient means to remove $\mathrm{CO}_{2}$ from biogas using vacuum pressure swing process using silica gel as adsorbent. Four bed vacuum pressure swing adsorption was used to capture $\mathrm{CO}_{2}$ in the test. The vacuum pressure swing process is a technique used to separate gases from its mixture by the use of adsorbent and applying pressure in order to adsorb target gas i.e. $\mathrm{CO}_{2}$. The $\mathrm{CH}_{4}$ purity decreases with increase in adsorption time and desorption pressure. It was found that using this method to purify biogas would yield a $\mathrm{CH}_{4}$ of purity greater than $98 \%$. Hence this method can be adopted to capture $\mathrm{CO}_{2}$ because of its low investment and cheaply available adsorbent i.e. silica gel [12]-[14]. Moreover, there are various purification techniques are suggested by the researchers.

\section{RESULTS AND DISCUSSION}

In this study we have discussed about the various sources of bio gas production and we found that at the time of production some amount of unusual gases such as; $\mathrm{CO} 2$ and $\mathrm{H} 2 \mathrm{~S}$ etc. gases are also produced that directly effects on the production of bio gas. To improve the production rate it is necessary to remove that $\mathrm{CO} 2$ and $\mathrm{H} 2 \mathrm{~S}$ gases from the bio gas. There are various type of bio gas purification processes are available. All the purification processes divided in to two ways that is Biological and physiochemical methods.

\section{CONCLUSIONS}

Both biological and physicochemical methods are applicable to purify the bio gas.

The biological purification methods huge area to explore.

Fixed bed and bio reactor purification method more suitable process.

The combination of these method provides the better S-capture efficiency, low media and operating costs, energy prices and socio-economic policies.

To find the better ways to produce the bio gas from composite of different material.

there are different types of sources available for the production but still required to find the better ways to produce the bio gas from composite of different material

\section{ACKNOWLEDGEMENT}

The manuscript is prepared by taking assistance from Accendere Knowledge Management Services Pvt. Ltd. We are thankful to them. We also express our gratitude to our teachers and mentor for guiding us throughout the work 


\section{REFERENCES}

1. M. E. Montingelli, S. Tedesco, and A. G. Olabi, "Biogas production from algal biomass: A review," Renew. Sustain. Energy Rev., vol. 43, pp. 961-972, 2015.

2. H. M. El-Mashad and R. Zhang, "Biogas production from co-digestion of dairy manure and food waste," Bioresour. Technol., vol. 101, no. 11, pp. 4021-4028, 2010.

3. Yadvika, Santosh, T. R. Sreekrishnan, S. Kohli, and V. Rana, "Enhancement of biogas production from solid substrates using different techniques - A review," Bioresour. Technol., vol. 95, no. 1, pp. 1-10, 2004.

4. N. Pannucharoenwong, A. Worasaen, C. Benjapiyaporn, J. Jongpluempiti, and P. Vengsungnle, "Comparison of bio-methane gas Wobbe index in different animal manure substrate," Energy Procedia, vol. 138, pp. 273-277, 2017.

5. M. Mahadevaswamy and L. V Venkataraman, "Bioconversion of poultry droppings for biogas and algal production," Agric. wastes, vol. 18, no. 2, pp. 93-101, 1986.

6. S.-M. Lee, G. H. Kim, and J.-H. Lee, "Bio-gas production by co-fermentation from the brown algae, Laminaria japonica," J. Ind. Eng. Chem., vol. 18, no. 4, pp. 1512-1514, 2012.

7. P. Weiland, "Biogas production: current state and perspectives," Appl. Microbiol. Biotechnol., vol. 85, no. 4, pp. 849-860, 2010.

8. M. Climent, I. Ferrer, M. del Mar Baeza, A. Artola, F. Vázquez, and X. Font, "Effects of thermal and mechanical pretreatments of secondary sludge on biogas production under thermophilic conditions," Chem. Eng. J., vol. 133, no. 1-3, pp. 335-342, 2007.

9. M. F.-D. Juárez, P. Mostbauer, A. Knapp, W. Müller, S. Tertsch, A. Bockreis, and H. Insam, "Biogas purification with biomass ash," Waste Manag., vol. 71, pp. 224-232, 2018.

10. S. Achinas, Y. Li, V. Achinas, and G. J. W. Euverink, "Influence of sheep manure addition on biogas potential and methanogenic communities during cow dung digestion under mesophilic conditions," Sustain. Environ. Res., vol. 28, no. 5, pp. 240-246, 2018.

11. W. J. Nock, M. Walker, R. Kapoor, and S. Heaven, "Modeling the water scrubbing process and energy requirements for $\mathrm{CO} 2$ capture to upgrade biogas to biomethane," Ind. Eng. Chem. Res., vol. 53, no. 32, pp. 12783-12792, 2014.

12. Y. Belmabkhout, G. De Weireld, and A. Sayari, "Amine-bearing mesoporous silica for $\mathrm{CO} 2$ and $\mathrm{H} 2 \mathrm{~S}$ removal from natural gas and biogas," Langmuir, vol. 25, no. 23, pp. 13275-13278, 2009.

13. N. Hedin, L. Andersson, L. Bergström, and J. Yan, "Adsorbents for the post-combustion capture of $\mathrm{CO} 2$ using rapid temperature swing or vacuum swing adsorption," Appl. Energy, vol. 104, pp. 418-433, 2013.

14. Y. Belmabkhout, N. Heymans, G. De Weireld, and A Sayari, "Simultaneous adsorption of $\mathrm{H} 2 \mathrm{~S}$ and $\mathrm{CO} 2$ on triamine-grafted pore-expanded mesoporous MCM-41 silica," Energy \& Fuels, vol. 25, no. 3, pp. 1310-1315, 2011. 